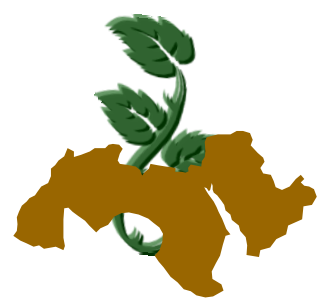

Arab Univ. J. Agric. Sci., Ain Shams Univ., Cairo, 16(2), 427-436, 2008

\title{
IMPROVEMENT OF QUALITY OF RAS CHEESE MADE FROM PASTEURIZED MILK USING A SPECIAL SLURRY FROM EWE'S MILK
}

\author{
Mehanna $^{1}$, N.M.; M.A.M. Moussa ${ }^{2}$ and A.A. Abd El-Khair ${ }^{3}$ \\ 1- Dairy Sci. Dept., Faculty of Agric., Kafr El-Sheikh Univ., Egypt \\ 2- Dairy Res. Dept. Animal Prod. Institute, Agric. Res. Center, Dokki, Egypt \\ 3- Food \& Dairy Sci. Dept., Faculty of Agric., Sohag Univ., Egypt
}

Keywords: Ras cheese, Pasteurized milk, Ewe's milk slurry)

\section{ABSTRACT}

The present study was carried out as an attempt to improve the quality of Ras cheese made from pasteurized cow's milk using ewe's milk slurry to which proteases and lipases were added. The slurry was incubated at $30^{\circ} \mathrm{C}$ for one week, and then added either to the cheese milk prior to coagulation or directly to the cheese curd before pressing. Cheeses were analysed for chemical, microbiological and organoleptic properties at $0,15,30$, 60 and $90 \mathrm{~d}$ of ripening. Generally, the addition of slurry affected at least four parameters of interest for the flavour development. Cheese flavour development was accelerated, the proteolysis was enhanced and casein breakdown was stimulated. Addition of slurry increased the levels of the total volatile fatty acids at each period of ripening, particularly with addition of slurry to cheese curd. Addition of slurry affected the microbiological quality of cheeses. Proteolytic and lipolytic bacterial counts increased throughout ripening, while yeast and moulds were no longer detectable in slurry added cheese after $30 \mathrm{~d}$ of ripening. Sensory evaluation showed that the Ras cheeses made with the slurry received higher scores for flavor and body and texture than the control cheese over $90 \mathrm{~d}$ of ripening. These results suggested that the addition of ewe's milk slurry was necessary for development of sensory characteristics of the cheeses.

\section{INTRODUCTION}

Ras cheese is an Egyptian most popular hard cheese, similar to Greek type "Kefalotyri". The popularity of this type of cheese is mainly due to its unique taste and aroma. Ras cheese is originally made in Egypt from cow's milk or from a mixture of cow's and buffalo's milk, but the used milk is usually raw (unpasteurized) milk. Under these unhygienic conditions a wide variety of pathogenic and undesirable microorganisms may be find their way through milk, cause risks and hazard spoilage and deterioration for the product.

Due to the high microbial load present in raw milk, pasteurization is commonly used to eliminate all pathogenic and most of non-pathogenic organisms before its further processing into cheese. Moreover, pasteurization of milk for cheese manufacture is intended mainly to reduce microbial load, ensure greater yield, high level of quality and ripening at higher temperature (Ordonez et al 1999).

Recently, there has been widespread national concern over the potential health risks to the general public from hazard spoilage in a variety of raw food products. Currently, regulations for safety and quality control in Egypt enforced that cheese milk must be pasteurized before manufacture to ensure a margin of safety for consumers.

Manufacture of Ras cheese from pasteurized milk lead to many problems in quality of the final product. These problems include; the lake of characteristic flavour and aroma, retardation of cheese ripening, surface dryness and texture fractures (Girgis et al 1999; Ayad 2004). The effect of heat treatment on milk aroma has been well documented. The same aroma intensity takes longer time to develop in cheeses made from pasteurized milk than in raw milk cheeses, if it can be attained at all (Mendia et al 1999). It is widely acknowledged that pasteurization influences the biochemistry of ripening by altering the indigenous microflora of the milk, partially or completely inactivating certain 
enzymes that contribute to ripening (Grappin and Beuvier 1997; Moatsou et al 2001).

Therefore, there is an interest in improving quality of Ras cheese made from pasteurized milk to meet consumer demands who looks for quality and originality. The challenge in Ras cheese made from pasteurized milk is to improve the sensory attributes of the product to produce a cheese that is comparable to its raw milk counterpart. Development of ways to overcome these problems in Ras cheese therefore can accelerate the ripening rate, improve overall quality and marketability, and make a safer product for the consumer. Recent development in Ras cheese research was reviewed by Abo-Donia (2002).

To produce cheeses with the same characteristics as raw milk cheeses, replenishment of the beneficial microorganisms destroyed by heating is necessary. Several approaches have been investigated for their potential to accelerate ripening and improve the flavor and texture of Kefalotyri (Ras) cheese, e.g. modification of conventional manufacturing process (Hofi et al 1970), addition of trace elements (Hofi et al 1973a), use of casein and whey protein hydrolysates (Hofi et al 1973b), use of enzymes (Abd El-Salam et al 1979), use of autolysed starters or specially designed adjunct cultures (Nassib 1974; Aly 1990; Ezzat and ElShafei 1991; El-Shafei, 1994; Katsiari et al 2002). Utilization of cheese slurries in acceleration of Kefalotyri (Ras) cheese ripening and enhancing flavour development has been also extensively investigated (Abd El-Baky et al 1982; Abd ElHamid et al 1991; Hofi et al 1991; Abo-Donia 2002).

The objective of the present study was to improve the quality of Ras cheese made from pasteurized cow's milk using ewe's milk slurry as a source of enzymes and microorganisms, since Kefalotyri cheese is traditionally made in Greece from ewe's milk.

\section{MATERIALS AND METHODS}

\section{Preparation of ewe's milk slurry}

Ewe's milk slurry was prepared from fresh ewe's milk, which was purchased from a local dairy farm. Proteolytic (protease, $0.004 \%$ ) and lipolytic (lipase, $0.001 \%$ ) enzymes were added to the salted curd directly prior to press. Cheese process was completed by the conventional manner. The resultant cheese was incubated at $30^{\circ} \mathrm{C}$ for about one month. The prepared slurry was then treated as follows; the slurry was mixed with $5 \%$ sodium chloride and $0.3 \%$ potassium sorbate. The resultant slurry was packed in tightly closed containers and stored at $30^{\circ} \mathrm{C}$ for approximately one week prior to use for Ras cheesemaking. Such preparation was done mainly as given by Abd El-Baky et al (1982).

\section{Ras cheese manufacture}

Fresh cow's milk was obtained from the herd of the Animal Prod. Res. Inst., Ministry of Agriculture (Sakha Station), Kafr El-Sheikh governorate, Egypt. The milk was heat treated at $72^{\circ} \mathrm{C}$ for $15 \mathrm{~s}$, and rapidly cooled to $32^{\circ} \mathrm{C}$ before used in cheese manufacture. Three different cheese batches were manufactured: a control batch was made from milk without added slurry (C); a second batch was made with adding slurry to cheese milk ( $\left.\mathbf{T}_{\mathbf{1}}\right)$; and a third batch was made with adding slurry directly to the salted curd before pressing ( $\left.\mathbf{T}_{2}\right)$. In $\mathbf{T}_{\mathbf{1}}$ and $\mathbf{T}_{\mathbf{2}}$, slurry was added at the rate of $1 \%$ of the cheese milk weight. All cheese batches were manufactured according to the method described by Hofi et al (1970). Two replicates were made, yielding duplicates of each batch. Finally, the cheese samples were allowed to ripen under controlled conditions of temperature and humidity before being taken for analysis. Two cheese samples were taken from each batch for analysis at $0,15,30,60$ and $90 \mathrm{~d}$ of ripening. All analyses were also performed in duplicate.

\section{Methods of analysis}

\section{Chemical analysis}

Cheese samples were analyzed for moisture, fat, salt and titratable acidity (TA) according to the methods of Association of Official Analytical Chemists (AOAC 1990). $\mathrm{pH}$ was measured using $\mathrm{pH}$ meter Jenway model 3020 (Jenway Ltd. Gransmore Green, Felsted, Dunmow, England)). Total nitrogen (TN), soluble nitrogen (SN) and nonprotein nitrogen (NPN) were determined by the semi-micro kjeldahl method. Total volatile fatty acids (TVFA) were determined by the distillation method described by Kosikowski (1970). Shilovich ripening index (SRI) was carried out according to Tawab and Hofi (1966).

\section{Electrophoresis analysis}

Proteolytic patterns of hydrolyzed and degraded cheese proteins were evaluated by polyacrylamide gel electrophoresis (SDS-PAGE) as described by Laemmli (1970). Precipitates of protein obtained from $\mathrm{N}$ fractionation were washed twice in 
distilled water, centrifuged, and freeze-dried. Five milligrams was dissolved in $1 \mathrm{ml}$ of $7 \mathrm{M}$ urea, and $25 \mu \mathrm{l}$ of $0.05 \%$ aqueous solution of bromophenol blue were added. Samples (15 $\mu$ l each) of this solution were taken for the electrophoretic separations. Alkaline urea-PAGE with 1-mm spacers was performed with $8.8 \%(\mathrm{w} / \mathrm{v})$ polyacrylamide and $5 \mathrm{M}$ urea at pH 8.9. Gels were stained with Coomassie Blue R-250 (Sigma Chemical Company, St. Louis, $\mathrm{MO}$ ) and destained by repeated washing in a solution of ethanol, acetic acid, glycerol, and water $(200: 50: 25: 725 \mathrm{v} / \mathrm{v})$.

\section{Microbiological analysis}

Cheese samples were examined for total bacteria, proteolytic bacteria, lipolytic bacteria, coliform, yeast and mold counts, according to American Public Health Association (APHA 1992). All experiments were repeated in triplicate and each analysis in duplicate.

\section{Organoleptic evaluation}

The organoleptic properties of the cheese samples were evaluated by a test panel of 5 panelists with maximum score points of 60,30 , and 10 for flavour, body \& texture, and appearance, respectively as given by Hofi et al (1991).

\section{Statistical analysis}

The obtained data were statistically analyzed using the one way ANOVA procedure. The PROC GLM procedure of (SAS, 1985) was used for all data analysis while, Duncan's multiple comparison was applied among treatments. The level of significance was set at $P<0.05$.

\section{RESULTS AND DISCUSSION}

\section{Chemical composition}

Table (1) shows that addition of ewe's milk slurry to the cheese milk or curd slightly decreased the moisture content of the resultant cheese. This was associated with an increase in the fat, protein and salt contents as a result of increasing the percentage of dry matter. Addition of the slurry to the curd was the most effective factor in this respect. The mean values of moisture contents of slurry added cheeses were 27.93 and $26.42 \%$ for $\mathrm{T}_{1}$ and $\mathrm{T}_{2}$, respectively compared to $33.43 \%$ for control cheese after $90 \mathrm{~d}$ of ripening.

Table 1. Chemical composition $(n=4)$ of control and treated cheeses during ripening period

\begin{tabular}{|c|c|c|c|c|c|c|c|}
\hline \multirow{3}{*}{ Treatments* } & \multirow{3}{*}{$\begin{array}{c}\text { Ripening } \\
\text { period } \\
\text { (days) }\end{array}$} & \multicolumn{6}{|c|}{ Chemical composition } \\
\hline & & \multirow{2}{*}{$\begin{array}{c}\text { Moisture } \\
\%\end{array}$} & \multicolumn{2}{|c|}{ Fat } & \multicolumn{2}{|c|}{ Protein } & \multirow{2}{*}{ Salt/DM } \\
\hline & & & $\%$ & Fat/DM & $\%$ & Protein /DM & \\
\hline \multirow[t]{5}{*}{ Control } & 0 & $36.95^{a}$ & $31.00^{\mathrm{b}}$ & $50.03^{a}$ & $24.90^{\mathrm{b}}$ & $39.48^{a}$ & $6.88^{c}$ \\
\hline & 15 & $37.38^{a}$ & $32.50^{b}$ & $51.91^{\mathrm{a}}$ & $25.55^{b}$ & $40.79^{a}$ & $7.14^{\mathrm{b}}$ \\
\hline & 30 & $37.05^{a}$ & $33.20^{b}$ & $52.70^{a}$ & $26.21^{a}$ & $41.62^{a}$ & $7.70^{b}$ \\
\hline & 60 & $36.15^{a}$ & $34.73^{b}$ & $54.19^{a}$ & $27.00^{a}$ & $42.46^{a}$ & $8.42^{b}$ \\
\hline & 90 & $33.43^{a}$ & $35.42^{b}$ & $53.90^{\mathrm{a}}$ & $27.15^{\mathrm{a}}$ & $40.84^{a}$ & $9.92^{\mathrm{a}}$ \\
\hline \multirow[t]{5}{*}{$\mathrm{T}_{1}$} & 0 & $33.68^{b}$ & $34.75^{a}$ & $51.41^{\mathrm{a}}$ & $26.01^{a}$ & $39.23^{a}$ & $10.03^{b}$ \\
\hline & 15 & $32.14^{b}$ & $36.25^{a}$ & $53.43^{a}$ & $26.49^{a, b}$ & $39.04^{b}$ & $11.00^{a}$ \\
\hline & 30 & $31.10^{b}$ & $37.17^{a}$ & $53.98^{a}$ & $26.77^{a}$ & $38.86^{b}$ & $11.89^{a}$ \\
\hline & 60 & $29.73^{b}$ & $37.50^{a}$ & $53.39^{a}$ & $27.53^{a}$ & $39.16^{a}$ & $12.63^{a}$ \\
\hline & 90 & $27.93^{b}$ & $39.17^{\mathrm{a}}$ & $54.35^{a}$ & $27.99^{a}$ & $38.82^{a}$ & $13.62^{\mathrm{a}}$ \\
\hline \multirow[t]{5}{*}{$\mathrm{T}_{2}$} & 0 & $33.10^{b}$ & $34.45^{a}$ & $51.91^{a}$ & $26.40^{a}$ & $39.84^{a}$ & $10.75^{a}$ \\
\hline & 15 & $31.58^{b}$ & $36.12^{a}$ & $52.79^{a}$ & $27.08^{a}$ & $39.59^{b}$ & $11.51^{\mathrm{a}}$ \\
\hline & 30 & $30.15^{b}$ & $37.03^{a}$ & $53.01^{a}$ & $27.67^{a}$ & $39.60^{a, b}$ & $12.38^{a}$ \\
\hline & 60 & $28.34^{b}$ & $37.83^{a}$ & $52.79^{a}$ & $28.34^{a}$ & $39.52^{a}$ & $13.23^{a}$ \\
\hline & 90 & $26.42^{b}$ & $40.17^{a}$ & $54.57^{a}$ & $29.23^{a}$ & $39.72^{a}$ & $14.23^{a}$ \\
\hline
\end{tabular}

- Control: Cheese made without adding slurry

- $\mathrm{T}_{1}$ : Slurry was added to cheese milk

- $\mathrm{T}_{2}$ : Slurry was added to cheese curd before pressing

- Means with the same letter in the same column are not significantly different. 
At the end of ripening period, the mean values of fat/DM, protein/DM and salt/DM (Table 1) in cheese from all treatments were insignificantly different, whereas their values throughout the ripening period were differed significantly. These values were different from those given by Awad et al (2003) for market Ras cheese and by Ayad (2004) for Ras cheese made from raw and pasteurized milk. Such differences may be due to the differences in composition between ewe's and cow's milks. Ewe's milk is higher in fat than cow's milk. With almost twice as much in the way of solids as cow's milk, and significantly higher in protein.

\section{Ripening indices}

Titratable acidity (TA) of cheese with slurry added either to cheese milk or curd was significantly $(\mathrm{P}<0.05)$ higher than that of the control (Table 2). The TA and $\mathrm{pH}$ values of control and slurry added cheeses for the corresponding ripening periods revealed that more lipolysis and proteolysis occurred in slurry added cheeses than control. The $\mathrm{pH}$ of all cheeses significantly decreased from the first day to $\mathrm{d} 30$ and remained almost constant thereafter. Results show also that Ras cheese made with adding slurry contained more total volatile fatty acids (TVFA) than the control cheese at each period of ripening. However, addition of cheese slurry to the curd was more effective in this respect than when it was added to the cheese milk.. The final concentration of TVFA in cheese to which slurry was added to the curd, was 2-3 times higher than that of control, while that value was higher than that of cheese made with addition of slurry to cheese milk. During ripening, protein in the cheese was hydrolyzed by proteases into smaller molecular compounds such as many kinds of peptides and amino acids. Therefore there should be a great increase in peptide and free amino acid content after ripening. In the present study, there was a significant difference in SRI between slurry added cheeses and control cheese reflecting the total free amino nitrogen content.

The same table shows also that SN/TN and NPN/TN values were significantly higher $(P<0.05)$ in $T_{1}$ and $T_{2}$ than those in control at any given ripening time. On the other hand, cheese from $\mathrm{T}_{2}$ had the highest values in this respect suggesting adding slurry to cheese curd was more effective in cheese ripening. Such impact can be attributed to presence of higher level of proteases remained in cheese during ripening. Similar trends were reported by Abdel Baky et al (1982) and Hofi et al
(1991) whereas the changes occurred during ripening are in agreement with those given in the literature (Abdel Salam et al 1979; Ayad 2004).

\section{Electrophoretic patterns}

Fig. (1) shows the electrophoretic patterns of control and slurry added cheese samples when fresh and at the end of ripening period. The principal protein regions were similar in number and relative mobility of the main protein fractions. Thus, all cheese samples showed common protein patterns which are divided into several bands, those of the fast moving fractions, as-casein, and the slow moving fractions of $\beta$-caseins, $\gamma_{1}, \gamma_{2}$ and $\gamma_{3}$ caseins. The fresh cheeses of all batches showed that $\mathrm{as}_{1}$-casein was the major casein band. The electrophoretic characteristics of casein fractions showed that the initial intensity of the as 1 -casein band was much greater than that of $\beta$-casein, and both casein bands became weaker at $90 \mathrm{~d}$ of ripening. The intensities of $\mathrm{Y}_{1}$-casein and small peptide bands became also faint at the end of ripening. The as 1 -casein showed many bands susceptible to the action of rennin and proteolytic enzymes of cheese flora. It can also be observed that, there were differences among the three cheese batches, hence, $T_{2}$ showed more proteolysis as compared with $T_{1}$ and the control. However, $T_{1}$ and $T_{2}$ showed more hydrolysis at the end of the ripening. All casein fractions of both $T_{1}$ and $T_{2}$ exhibited highly protein proteolysis as compared with control, particularly their as-casein, showing an extensive breakdown. This result might be due to that the addition of slurry stimulated the activity of both external and internal proteolytic enzymes of starter bacteria. The degradation of large molecular caseins clearly increased protein degradation products, which in turn caused the elevation of SN and NPN contents of the corresponding cheeses (Table 2). The degradation of the as 1 -and $\beta$ caseins during ripening in this study also agree with results of previous reports (Macedo and Malcata 1997; Awad et al 2003; Kalavrouzioti et al 2005). These authors reported that the hydrolysis of $\alpha_{s}$ - casein was more rapid than $\beta$ - casein.

\section{Microbiological properties}

Table (3) shows that the total bacterial counts (TBC) increased by slurry addition and decreased by ripening period, but the differences between the different treatments over the ripening period were 
Table 2. Ripening indices $(n=4)$ of control and treated cheeses during ripening period

\begin{tabular}{|cccccccc|}
\hline \multirow{2}{*}{ Treatments $^{*} \begin{array}{c}\text { Ripening } \\
\text { period } \\
\text { (days) }\end{array}$} & $\begin{array}{c}\text { TA } \\
(\%)\end{array}$ & $\begin{array}{c}\text { pH } \\
\text { value }\end{array}$ & TVFA $^{\star \star}$ & SRI & SN/TN \# \\
$\%$ & $\begin{array}{c}\text { NPN/TN } \\
\%\end{array}$ \\
\hline Control & 0 & $0.65^{\mathrm{b}}$ & $5.28^{\mathrm{a}}$ & $6.15^{\mathrm{b}}$ & $27.83^{\mathrm{a}}$ & $4.87^{\mathrm{a}}$ & $1.43^{\mathrm{a}}$ \\
& 15 & $0.84^{\mathrm{a}}$ & $5.08^{\mathrm{a}}$ & $8.04^{\mathrm{b}}$ & $47.83^{\mathrm{a}}$ & $5.99^{\mathrm{b}}$ & $1.89^{\mathrm{a}}$ \\
& 30 & $1.50^{\mathrm{a}}$ & $4.67^{\mathrm{a}}$ & $9.82^{\mathrm{b}}$ & $62.83^{\mathrm{a}}$ & $7.38^{\mathrm{b}}$ & $2.72^{\mathrm{b}}$ \\
& 60 & $1.77^{\mathrm{a}}$ & $4.37^{\mathrm{a}}$ & $11.36^{\mathrm{c}}$ & $75.00^{\mathrm{a}}$ & $8.79^{\mathrm{b}}$ & $3.77^{\mathrm{a}}$ \\
& 90 & $1.28^{\mathrm{b}}$ & $4.86^{\mathrm{a}}$ & $12.89^{\mathrm{c}}$ & $95.33^{\mathrm{a}}$ & $9.42^{\mathrm{b}}$ & $4.71^{\mathrm{a}}$ \\
\hline $\mathrm{T}_{1}$ & 0 & $0.86^{\mathrm{a}}$ & $5.15^{\mathrm{a}}$ & $15.79^{\mathrm{a}}$ & $32.00^{\mathrm{a}}$ & $5.15^{\mathrm{a}}$ & $1.77^{\mathrm{a}}$ \\
& 15 & $1.04^{\mathrm{a}}$ & $4.93^{\mathrm{a}}$ & $18.02^{\mathrm{a}}$ & $43.50^{\mathrm{b}}$ & $7.08^{\mathrm{a}, \mathrm{b}}$ & $2.54^{\mathrm{a}}$ \\
& 30 & $1.42^{\mathrm{a}}$ & $4.70^{\mathrm{a}}$ & $20.52^{\mathrm{a}}$ & $56.33^{\mathrm{a}} \mathrm{b}$ & $8.40^{\mathrm{a}, \mathrm{b}}$ & $3.53^{\mathrm{a}, \mathrm{b}}$ \\
& 60 & $1.49^{\mathrm{a}}$ & $4.59^{\mathrm{a}}$ & $24.42^{\mathrm{b}}$ & $70.67^{\mathrm{b}}$ & $9.99^{\mathrm{a}, \mathrm{b}}$ & $4.38^{\mathrm{a}}$ \\
& 90 & $2.04^{\mathrm{a}}$ & $4.44^{\mathrm{a}}$ & $30.02^{\mathrm{b}}$ & $87.50^{\mathrm{b}}$ & $11.22^{\mathrm{a}, \mathrm{b}}$ & $5.71^{\mathrm{a}}$ \\
\hline $\mathrm{T}_{2}$ & 0 & $0.85^{\mathrm{a}}$ & $5.28^{\mathrm{a}}$ & $17.09^{\mathrm{a}}$ & $31.67^{\mathrm{a}}$ & $5.02^{\mathrm{a}}$ & $2.31^{\mathrm{a}}$ \\
& 15 & $1.09^{\mathrm{a}}$ & $4.93^{\mathrm{a}}$ & $19.96^{\mathrm{a}}$ & $43.50^{\mathrm{b}}$ & $7.55^{\mathrm{a}}$ & $2.90^{\mathrm{a}}$ \\
& 30 & $1.31^{\mathrm{a}}$ & $4.68^{\mathrm{a}}$ & $22.35^{\mathrm{a}}$ & $54.83^{\mathrm{b}}$ & $8.96^{\mathrm{a}}$ & $4.21^{\mathrm{a}}$ \\
& 60 & $1.46^{\mathrm{a}}$ & $4.59^{\mathrm{a}}$ & $31.52^{\mathrm{a}}$ & $70.67^{\mathrm{b}}$ & $10.74^{\mathrm{a}}$ & $5.11^{\mathrm{a}}$ \\
& $9.11^{\mathrm{a}}$ & $4.38^{\mathrm{a}}$ & $35.44^{\mathrm{a}}$ & $89.00^{\mathrm{a}, \mathrm{b}}$ & $12.14^{\mathrm{a}}$ & $6.34^{\mathrm{a}}$ \\
\hline
\end{tabular}

* Treatments: See legend of Table (1) for details

**TVFA: Total volatile fatty acids expressed as $\mathrm{ml} 0.1 \mathrm{~N} \mathrm{NaOH} / 100 \mathrm{~g}$ of cheese

***SRI: Shilovich ripening index expressed as $\mathrm{ml} 0.1 \mathrm{~N} \mathrm{NaOH} / 100 \mathrm{~g}$ of cheese

\# SN/TN: Soluble nitrogen/Total nitrogen $x 100$

- NPN/TN: Non-protein nitrogen/Total nitrogen x100

- Means with the same letter in the same column are not significantly different.

Table 3. Microbiological properties $(n=4)$ of control and slurry added cheeses during ripening period

\begin{tabular}{|c|c|c|c|c|c|}
\hline Treatments* & $\begin{array}{l}\text { Ripening } \\
\text { period } \\
\text { (d) }\end{array}$ & $\begin{array}{c}\text { Total bacterial } \\
\text { count } \times 10^{6}\end{array}$ & $\begin{array}{c}\text { Lipolytic } \\
\text { bacterial count } \\
\times 10^{2}\end{array}$ & $\begin{array}{c}\text { Proteolytic } \\
\text { bacterial count } \\
\times 10^{2}\end{array}$ & $\begin{array}{l}\text { Yeast and } \\
\text { mold counts } \\
\times 10^{2}\end{array}$ \\
\hline \multirow[t]{5}{*}{ Control } & 1 & $172.0^{a}$ & $1.05^{b}$ & $2.13^{b}$ & $2.16^{b}$ \\
\hline & 15 & $99.2^{a}$ & $1.93^{b}$ & $3.30^{a}$ & $1.88^{a}$ \\
\hline & 30 & $74.2^{a}$ & $2.57^{b}$ & $5.75^{b}$ & $1.51^{\mathrm{a}}$ \\
\hline & 60 & $56.2^{a}$ & $3.64^{b}$ & $9.49^{c}$ & $1.33^{a}$ \\
\hline & 90 & $24.8^{a}$ & $5.03^{b}$ & $12.43^{a}$ & $1.25^{\mathrm{a}}$ \\
\hline \multirow[t]{5}{*}{$\mathrm{T}_{1}$} & 1 & $177.3^{a}$ & $1.15^{b}$ & $2.80^{a}$ & $3.69^{a}$ \\
\hline & 15 & $106.3^{a}$ & $2.27^{b}$ & $3.68^{a}$ & $1.28^{a, b}$ \\
\hline & 30 & $83.5^{a}$ & $3.80^{a, b}$ & $8.65^{a, b}$ & N.D \\
\hline & 60 & $62.5^{a}$ & $6.89^{b}$ & $13.82^{b}$ & N.D \\
\hline & 90 & $28.5^{a}$ & $10.78^{a}$ & $18.85^{b}$ & N.D \\
\hline \multirow[t]{5}{*}{$\mathrm{T}_{2}$} & 1 & $182.7^{a}$ & $1.61^{a}$ & $3.02^{a}$ & $3.67^{a}$ \\
\hline & 15 & $110.3^{a}$ & $3.80^{a}$ & $3.92^{a}$ & $1.12^{b}$ \\
\hline & 30 & $86.8^{a}$ & $7.07^{a}$ & $10.47^{a}$ & N.D \\
\hline & 60 & $65.8^{a}$ & $10.87^{a}$ & $17.33^{a}$ & N.D \\
\hline & 90 & $37.0^{a}$ & $13.80^{a}$ & $22.83^{a}$ & N.D \\
\hline
\end{tabular}

* Treatments: See legend of Table (1) for details

- All cheese samples were free from coliform bacteria

- Means with the same letter in the same column are not significantly different. 
still not significant. Changes in lactic acid bacteria in ripening Kefalotyri cheese were studied by Litopoulou-Tzanetaki (1990) who found that, leuconostocs, lactic streptococci and betabacteria disappeared early in ripening while, lactobacilli and enterococci became predominant with ripening. The author suggested that a starter consisting of both lactic acid bacteria that disappeared early and that survived throughout ripening should be preferable for the production of Kefalotyri cheese. Proteolytic and lipolytic bacterial counts of cheeses also increased with slurry addition (Table 3 ). The respective proteolytic and lipolytic bacterial counts of the control and slurry added cheeses for the corresponding ripening periods, showed an opposite trend to TBC counts, where the former counts increased progressively throughout ripening, reaching the maximum, in general, at $90 \mathrm{~d}$. There were no detectable levels of coliform in all cheeses either when fresh or during the ripening period. However, this result was expected, because of the effect of milk pasteurization. Yeast and mold counts of the slurry added cheeses significantly $(\mathrm{P}<0.05)$ decreased with slurry addition. Ripening period also caused a significant reduction in yeast and mold counts. Similar microbial profile during ripening of Ras cheese was described elsewhere (Abdel Baky et al 1982; Litopoulou-Tzanetaki 1990) whereas, greatly different microbial profile was obtained by Awad et al (2003) for market Ras cheeses made from raw milk. Egyptian Standards for Ras Cheese (E.S 2001) stated that the cheese must be completely free from pathogenic microorganisms and the counts of coliforms, molds and yeast should not be exceed than 10, 10 and $10^{2}$ $\mathrm{cfu} / \mathrm{g}$, respectively.

Recently, a great attention was given for the flora of Ras cheese aiming to improve the quality when pasteurized milk is used in its making. Abdella et al (2006 a,b) studied the effect of seasonal variations and place of production on natural flora of Ras cheese, whereas Ayad et al (2006) demonstrated that, a total of 1340 strains of $L A B$ were identified from 114 cheese samples obtained during manufacture of ripening artisanal Ras cheese produced in different regions of Egypt. However, no single technology can ensure a safe cheese, a high degree of safety can be achieved in a system that combines a number of antimicrobial effects. These include the synergistic effects arising from the use of starter cultures, the relatively high salt content, the acidification process (with $\mathrm{pH}$ falling to 5.5 or lower, depending on the cheese), declining moisture content, storage temperature, the development of enzyme systems, and the length of the maturation period, all of which serve to eliminate pathogenic bacteria (Donnelly 2001).

\section{Organoleptic properties}

It was clear from Table (4) that Ras cheese made with adding slurry to either cheese milk or the curd had a higher total score than the control. Meanwhile, the former cheeses at age of $30 \mathrm{~d}$ showed a flavour intensity and body characteristics as the latter one of 3 months of ripening. The effect of slurry addition was more pronounced when it was added to the curd rather than to cheese milk.

Similar results were reported by Hofi et al (1991) for Ras cheese and by Katsiari et al (2002) for the hard ewe's milk cheese of the Kefalograviera-type using commercially available adjunct cultures. Ayad et al (2004) reported that the sensory results of commercial Ras cheese made from raw milk indicated that typical Ras cheese are tasty, piquant and sharp in flavour, neither too hard nor soft in the texture, and the body includes some mechanical and gaseous openings, and the colour is regular. On the other hand, Ayad (2004) found also that sensory data of Ras cheese from raw and pasteurized milk revealed that raw milk cheese received the highest flavour and texture scores, in spite of two different starter cultures were used in pasteurized milk cheese. Such two pasteurized milk cheeses had different taste, hard texture, more compact body, with fewer gaseous holes and cracks.

\section{CONCLUSION}

Ras cheese made with added ewe's milk slurry developed within $90 \mathrm{~d}$ of ripening a higher intensity flavour and better body and texture than those of cheese made from pasteurized cow's milk ripened for the same period. Slurry added cheese showed after ripening for $30 \mathrm{~d}$ a strong flavour similar to that of $60 \mathrm{~d}$ control cheese. The effectiveness of the addition ewe's milk slurry in enhancing of flavour development was more pronounced when slurry was incorporated directly into cheese curd before pressing. Manufacture of Ras cheese from pasteurized cow's milk with adding ewe's milk slurry can be considered an effective way for producing a good quality cheese. 
Table 4. Organoleptic properties $(n=4)$ of control and treated cheeses during ripening period

\begin{tabular}{|c|c|c|c|c|c|}
\hline \multirow[b]{2}{*}{ Treatments* } & \multirow{2}{*}{$\begin{array}{l}\text { Ripening } \\
\text { period } \\
\text { (d) }\end{array}$} & \multicolumn{4}{|c|}{ Attributes } \\
\hline & & $\begin{array}{l}\text { Flavour } \\
(60)\end{array}$ & $\begin{array}{c}\text { Body \& Texture } \\
(30)\end{array}$ & $\begin{array}{c}\text { Appearance } \\
\text { (10) }\end{array}$ & $\begin{array}{l}\text { Total } \\
(100)\end{array}$ \\
\hline \multirow[t]{5}{*}{ Control } & 0 & $25.7^{b}$ & $15.7^{b}$ & $3.7^{b}$ & $45.0^{b}$ \\
\hline & 15 & $28.7^{b}$ & $18.0^{b}$ & $5.0^{b}$ & $51.7^{b}$ \\
\hline & 30 & $31.7^{b}$ & $19.3^{c}$ & $5.7^{b}$ & $56.3^{b}$ \\
\hline & 60 & $34.0^{b}$ & $20.7^{c}$ & $5.7^{b}$ & $60.3^{b}$ \\
\hline & 90 & $37.3^{b}$ & $21.7^{c}$ & $6.0^{\mathrm{b}}$ & $65.0^{\mathrm{b}}$ \\
\hline \multirow[t]{5}{*}{$\mathrm{T}_{1}$} & 0 & $31.7^{\mathrm{a}}$ & $20.0^{a}$ & $5.3^{a}$ & $57.0^{a}$ \\
\hline & 15 & $36.3^{a}$ & $23.3^{a}$ & $6.3^{a}$ & $66.0^{\mathrm{a}}$ \\
\hline & 30 & $40.3^{a}$ & $25.7^{b}$ & $6.7^{\mathrm{a}, \mathrm{b}}$ & $72.7^{a}$ \\
\hline & 60 & $45.0^{a}$ & $26.7^{b}$ & $7.7^{\mathrm{a}}$ & $79.3^{a}$ \\
\hline & 90 & $51.0^{a}$ & $27.3^{b}$ & $8.3^{a}$ & $86.7^{a}$ \\
\hline \multirow[t]{5}{*}{$\mathrm{T}_{2}$} & 0 & $34.3^{a}$ & $22.7^{a}$ & $6.0^{a}$ & $63.0^{a}$ \\
\hline & 15 & $40.0^{a}$ & $26.0^{a}$ & $6.7^{\mathrm{b}}$ & $72.7^{a}$ \\
\hline & 30 & $44.0^{a}$ & $27.3^{a}$ & $7.3^{a}$ & $78.7^{a}$ \\
\hline & 60 & $50.3^{a}$ & $28.7^{a}$ & $8.3^{a}$ & $87.3^{a}$ \\
\hline & 90 & $56.7^{a}$ & $29.0^{a}$ & $9.0^{a}$ & $94.7^{\mathrm{a}}$ \\
\hline
\end{tabular}

* Treatments: See legend of Table (1) for details

- Means with the same letter in the same column are not significantly different.

\section{REFERENCES}

Abdallah, H.M.; E.H.E. Ayad; S.M. Darwish and M. El-Soda (2006a). Effect of seasonal variations on natural flora, chemical composition and organoleptic properties of artisanal Egyptian Ras cheese. Egyptian J. Dairy Sci., 34: 87-101.

Abdallah, H.M.; E.H.E. Ayad; S.M. Darwish and M. El-Soda (2006b). Effect of place of production on natural flora of artisanal Egyptian Ras cheese. J. Adv. Agric. Res. (Fac. Agric., Saba Basha), 11: 621-638.

Abdel Baky, A.A.; A.M. El-Fak; A.M. Rabie and A.A. El-Neshawy (1982). Cheese slurry in the acceleration of Cephalotyre (Ras) cheese ripening. J. Food Prot. 45:894-897.

Abdel Hamid, L.B.; G.A. Mahran; H.M. Abbas and A.A. Hofi (1991). Ample production conditions for Ras cheese slurry. Egyptian J. Dairy Sci. 19: 327-335.
Abdel Salam, M.H.; A.A. Mohamed; E. Ayad; N. Fahmy and S. El-Shibiny (1979). Changes in the quality and chemical composition of Ras cheese by some commercial enzyme preparations. Egyptian J. Dairy Sci., 7: 63-74.

Abou-Donia, S.A. (2002). Recent development in Ras cheese research: A review. Egyptian J. Dairy Sci. 30:155-166.

Aly, M.E. (1990). Utilization of freeze-shocked lactobacilli for enhancing flavour development of Ras cheese. Nahrung 34: 329-335.

American Public Health Association (1992). Compendium of Methods for The Microbiological Examination of Foods. 3Ed. pp. 675-800. (Vanderzant, C. and D. Splittoesser eds), Washington D.C., USA.

Association of Official Analytical Chemists (1990). Official Methods of Analysis, $15^{\text {TH }}$ Ed. Association of Official Analytical the Chemists. Inc., Wilson Boulevard, Arlington, USA. 
Awad, S.; A. El-Attar; E.H.E. Ayad and M. ElSoda (2003). Characteristics of Egyptian Ras cheese; 1 Sensory evaluation, rheological, physico-chemical properties and microbiological analysis. Egyptian J. Dairy Sci., 31: 289-303.

Ayad, E.H.E. (2004). Flavour formation of Egyptian Ras cheese made from raw and pasteurized milk. Proc. The $9^{\text {th }}$ Egyptian Conf. for Dairy Sci. \& Tech., pp. 509-532. International Agriculture Centre, Dokki, Cairo.

Ayad, E.H.E.; S. Awad; A. El-Attar; C. de Jong and M. El-Soda (2004). Characterisation of Egyptian Ras cheese. 2. Flavour formation. Food Chemistry, 86: 553-561.

Ayad, E.H.E.; H.M. Abdallah; S.M. Darwish and M. El-Soda (2006). Identification of lactic acid bacteria of artisanal Egyptian Ras cheese. Egyptian J. Dairy Sci., 34: 139-149.

Donnelly, C. (2001). Factors associated with hygienic control and quality of cheeses prepared from raw milk: A review. Bulletin of the Int. Dairy Federation 369: 16-27.

Egyptian Standards for Ras Cheese (2001). Part 5 ES: 1007/2001. Ministry of Industry and Technological Development, Cairo.

El-Shafei H. (1994). Accelerated ripening of Ras cheese using cell free extract, freeze-and heatshocked Leuconostoc spp. cultures. Nahrung 38: 599-605.

Ezzat N. and H. El-Shafei (1991). Acceleration ripening of Ras cheese using freeze and heatshocked Lactobacillus helveticus. Egyptian J. Dairy Sci. 19: 347-358.

Girgis. E.S.; I.H.I. Abd El-Ghany; L.M. Youssef and L.M. Mohamed (1999). Effect of milk pretreatment and storage condition on the properties and keeping quality of Ras cheese. Egyptian $\mathbf{J}$. Dairy Sci., 27: 153-166.

Grappin, R. and E. Beuvier (1997). Possible implications of milk pasteurization on the manufacture and sensory quality of ripened cheese. Int. Dairy J. 7: 751-761.

Hofi, A.A.; E.H. Youssef; M.A. Ghoneim and G.A. Tawab (1970). Ripening changes in Cephalotyre (Ras) cheese manufactured from raw and pasteurized milk with special reference to flavour. J. Dairy Sci., 53: 1207-1211.

Hofi, A.A.; G.A. Mahran; M.H. Abdel Salam and I.D. Rifaat (1973a). Acceleration of Cephalotyre (Ras) cheese ripening by using trace elements. II. Optimum conditions. Egyptian J. Dairy Sci., 1: 45-54.
Hofi, A.A.; G.A. Mahran; M.Z. Ashour and S. Farahat (1973b). The use of casein and whey proteins hydrolysates in Ras cheese making. Egyptian J. Dairy Sci., 1: 79-83.

Hofi, A.A.; L.B. Abdel Hamid; N.S. Ahmed and H.M. Abbas (1991). Acceleration of Ras cheese ripening by relevant slurry. Egyptian J. Dairy Sci., 19: 337-346.

Kalavrouzioti, I.; M. Hatzikamari; E. LitopoulouTzanetaki and N. Tzanetakis (2005). Production of hard cheese from caprine milk by the use of two types of probiotic cultures as adjuncts. Int. J. Dairy Technol., 58: 30-38, 39.

Katsiari, M.C.; L.P. Voutsinas and E. Kondyli (2002). Improvement of sensory quality of low-fat Kefalograviera-type cheese with commercial adjunct cultures. Int. Dairy J. 12: 757-764.

Kosikowski, F.V. (1970). Cheese and Fermented Milk Foods (3 ${ }^{\text {rd }}$ Ed.), pp. 352-354. Edwards Brothers, Inc., Ann Arbor, Michigan, USA.

Laemmli, U.K. (1970). Cleavage of structural proteins during the assembly of the head of bacteriophage T4. Nature 227: 680- 685 .

Litopoulou-Tzanetaki, E. (1990). Changes in numbers and kinds of lactic acid bacteria during ripening of Kefalotyri cheese. J. Food Sci. 55: 111-113.

Macedo, A.C. and F.X. Malcata. (1997). Hydrolysis of as- and $\beta$-caseins during ripening of Serra cheese. Food Chem., 58: 43- 48.

Mendia, C.; F.C. Ibanez; P. Torre and Y. Barcina. (1999). Effect of pasteurization on the sensory characteristics of a ewe's-milk cheese. J. Sensory Stud. 14: 415-424.

Moatsou, G.; J. Kandarakis; K. Moushopolou; E. Anifantakis and E. Alichanidis (2001). Effect of technological parameters on the characteristics of Kasseri cheese from raw and pasteurized ewes milk. Int. Dairy J. 54: 69-77.

Nassib, T.A. (1974). Acceleration of El Ras cheese ripening by using autolysed starters. Assuit J. Agric. Sci. 5: 123-130.

Ordonez, A.I.; F.C. Ibanez; P. Torre and Y. Barcina (1999). Effect of ewes milk pasteurization on the free amino acids in Idiazabal cheese. Int. Dairy J., 9: 135-141.

SAS@ User's Guide (1985). Statistics, Version 5 Ed. SAS Inst.. Inc., Cary, NC.

Tawab, G.A. and A.A. Hofi (1966). Testing cheese ripening by rapid chemical techniques. Indian J. Dairy Sci., 19: 39-41. 